\author{
Abstracta Iranica \\ Abstracta Iranica Revue bibliographique pour le domaine irano-aryen \\ Volume 32-33 | 2013 \\ Comptes rendus des publications de 2009-2010
}

\title{
Edward Lipiński. Resheph. A Syro-Canaanite Deity
}

\section{Astrid Nunn}

\section{(2) OpenEdition}

\section{Journals}

Édition électronique

URL : http://journals.openedition.org/abstractairanica/40370

DOI : 10.4000/abstractairanica.40370

ISSN : 1961-960X

Éditeur :

CNRS (UMR 7528 Mondes iraniens et indiens), Éditions de l'IFRI

\section{Édition imprimée}

Date de publication : 1 décembre 2013

ISSN : 0240-8910

\section{Référence électronique}

Astrid Nunn, «Edward Lipiński. Resheph. A Syro-Canaanite Deity », Abstracta Iranica [En ligne], Volume 32-33 | 2013, document 96, mis en ligne le 01 juillet 2016, consulté le 02 octobre 2020. URL : http:// journals.openedition.org/abstractairanica/40370 ; DOI : https://doi.org/10.4000/abstractairanica. 40370

Ce document a été généré automatiquement le 2 octobre 2020.

Tous droits réservés 


\title{
Edward Lipiński. Resheph. A Syro- Canaanite Deity
}

\author{
Astrid Nunn
}

\section{RÉFÉRENCE}

Edward Lipiński. Resheph. A Syro-Canaanite Deity. Louvain, Peeters, 2009, 296 p., 1 pl. couleur et 9 ill. (Orientalia Lovaniensia Analecta 181 et Studia Phoenicia 19)

1 Resheph est un des grands dieux protecteurs cananéens attesté sur une période d'environ 2500 ans. Les trouvailles accumulées ces dernières décennies ont poussé l'A. à faire une nouvelle synthèse. Celle-ci repose sur les textes mais englobe aussi l'aspect iconographique. L'histoire de Resheph remonte à une époque beaucoup plus ancienne que l'époque achéménide. Le chapitre VI (p. 223-248) est consacré à Resheph en Syrie et Palestine au $\mathrm{I}^{\mathrm{er}}$ mill. av. J.-C. La plupart des textes sont araméens, phéniciens et hébreux et remontent au $\mathrm{VIII}^{\mathrm{e}}-\mathrm{VII}^{\mathrm{e}}$ siècles. Quelques inscriptions néanmoins - de Sidon entre autres - sont grecques et plus récentes. La datation du relief rupestre de Wadi Aššur au $\mathrm{XIII}^{\mathrm{e}} \mathrm{s}$. (Ramses II) reste à démontrer avec plus d'arguments.

\section{AUTEURS}

\section{ASTRID NUNN}

Université de Munich 